\title{
Sarah Wells: striving for holistic care
}

\section{A GP in a former life, the consultant and medical director found her place in palliative care}

\section{Inspirations}

I wanted to be a doctor from an early age and was endlessly supported by my mum, dad, and sister. Throughout my career my husband has encouraged and nurtured my progression.

\section{GP training}

I've always wanted to provide holistic care and thought general practice would let me do that. At the time you could either go on a GP vocational training programme or could apply, as I did, for sixth month jobs. So after graduating, I put together my own GP programme.

\section{Palliative care}

As part of my GP training I spent six months at Hayward House Hospice in Nottingham and I loved it so passionately that a light bulb went on in my head. It was so different to anything I had come across in medicine before-but I was still adamant that I wanted to continue training in general practice.

\section{GP partner}

In 2002 I became a GP partner in Erdington and I worked there alongside being a clinical assistant at John Taylor Hospice. As a GP I was frustrated that I didn't have enough time to manage patients holistically, which made me realise that palliative care was where I wanted to be.

\section{Staff grade}

In 2004 I moved to Marie Curie Hospice in Solihull as a staff grade doctor. I had two wonderful medical directors who encouraged my involvement in lots of different areas, including the inpatient unit, community, and outpatients. I also set up education programmes for GPs and community, hospice, and hospital staff.

\section{CESR}

I decided I wanted to become a consultant because I realised that as a specialty doctor you don't have the same autonomy. I decided to take the certificate of eligibility for specialist registration (CESR) route which meant putting together a portfolio of evidence to show I had the right training. It was intense and it took me three years, but I got my consultancy in October 2011.

\section{Balance}

I am very focused on self care. I know that I need a balance and I do things like spend time with my family, read, swim, and walk. I also have clinical supervision where I talk to a psychotherapist once a month, which is paid for by the hospice. That is really important.

\section{Medical director}

I became medical director of the hospice in 2015. I work three and a half days a week as medical director and inpatient unit consultant. Another day is spent as Marie Curie business owner of our two electronic patient records across all nine hospices.

\section{Fundraisers}

We are very reliant on our fundraising team. To do their job properly they need to understand what we're doing in the hospice so we've started inviting members of the team to join our ward rounds. They have found it enlightening, emotional, and hard. It's been so successful that we've invited people from our head office to come and join a ward round too.

\section{Career timeline}

2015 to present Medical director, palliative care consultant, Marie Curie Hospice, West Midlands.

2015 to present Consultant adviser to the paperless hospices project and business owner of SystOne and Emis

2011-2015 Consultant in palliative care, Marie Curie Hospice, West Midlands

Locum appointment for training in palliative care, St Mary's Hospice, Birmingham

Locum appointment for training in palliative care, Worcester General Hospital

2008-2010 Staff grade in palliative medicine, Heart of England foundation trust

2004-2011 Staff grade in palliative medicine, Marie Curie Hospice, Solihull 2002-2004 GP principal, Streetly Road surgery and clinical assistant at John Taylor Hospice

1999-2002 Salaried GP with development role

Senior house officer in palliative medicine, Hayward House, Nottingham City Hospital 